\title{
The African National Congress (ANC) and Its Ideological Shifts Over Time: Attempts to Define or Re-Define Its Ideological Identity?
}

\author{
Chitja Twala \\ Faculty of the Humanities, Department of History, University of the Free \\ State, Bloemfontein, South Africa \\ Email: twalacm@ufs.ac.za
}

\section{Doi:10.5901/mjss.2014.v5n20p1988}

\begin{abstract}
The study investigates the ideological challenges facing the African National Congress (ANC) from being a liberation movement to it becoming the ruling party in South Africa. The study argues whether there has been an ideological evolution within the ANC or not. Furthermore, the study contends that what the ANC aspired to ideologically, as a liberation movement prior to democratisation in April 1994, is not the same as what it is confronted with as the current ruling party in South Africa. It is clear from this study that the ANC has experienced some changes from its founding principles of 1912. With a number of political changes in the South African political landscape and the changes in the challenges confronting the movement over time, the party was bound to undergo some evolutionary progress. It is argued in this study that theorising about the ideologies of liberation movements are meaningless unless the mapping out of the courses of these ideological shifts of fundamentally defining and re-defining the status of such movements over time is undertaken. Therefore, this study traces how such an evolution has happened within the ANC and what ideological impact it has had on the history of the movement.
\end{abstract}

Keywords: Ideology, Politics, Leadership, Challenges, Democracy, Change

\section{Introduction}

In his Special Presidential Message to the African National Congress's (ANC's) Annual Conference held in Bloemfontein on 17-18 December 1955, Chief Albert Luthuli made a plea to the movement and its allies to aspire to furthering the national history of the African people, despite the almost insurmountable obstacles put in its way by the apartheid government. He warned that the ANC should not dissipate its energies by indulging in internal ideological feuds; a fight on 'isms'. However, this did not imply that the ANC had to expose itself as having a 'colourless ideology'. Therefore, it was incumbent upon the party to ideologically define or re-define itself. The ANC had made African Nationalism its philosophic basis of the liberation struggle in South Africa. This meant that the fighters for freedom in Africa had to be mobilised under its banner. The ANC was not immune to these continental developments. Having accepted the fact of the multiracial nature of South Africa, the ANC envisaged an All Inclusive African Nationalism which would rest on the principle of 'Freedom for All' and 'Unity for All'.

In January 2012, the ANC had huge centenary celebrations in South Africa and outside the country. Without doubt, for the ANC to have reached the 100-year mark that came with different challenges to the movement is laudable. There were leadership and membership challenges which needed the movement to undergo some introspection to ensure its continued survival. Besides the above, there were also some policy changes by the movement in order to determine its relevance to the masses, either in exile or within South Africa. The study gives an historical perspective on the ideological evolution of the ANC in its attempts to define and re-define itself over a period of time. Furthermore, the study provides a multidimensional perspective of the valuations and ethical decisions based on the ANC's ideology and how these influenced the lives of the South Africans. The scope of the study does not, in any way attempt to be exhaustive on the topic under scrutiny. However, it aims to provide a broader understanding of the ideological changes that the movement has experienced. A broad literature study was carried out and, as contemporary history, oral testimonies were presented.

\section{Historical Background to the Ideological Underpinnings of the ANC Over Time}

From time to time (or over a continuation of time), an individual or group of individuals promote or sustain a specific ideology by way of language use (and/or other means they wish to apply) in an effort to persuade potential 'believers' and 
followers of such an ideology. In order to fully comprehend the ideologies of the ANC, background information on the formation of the movement is crucial. The ANC was founded in Bloemfontein on 8 January 1912 at a place known as Waaihoek. The foundation of the ANC was based on some racial divisions that the Africans experience in South Africa (Odendaal 2012: pp466-473). When the ANC was founded, one of its ideological missions was to unite all Africans in South Africa in order to challenge the racially divisive attempts by the then ruling party. Traditional leaders, lawyers, clerks, teachers and ministers of religion heeded the call and descended on Bloemfontein in January 1912 for the formation of the ANC (Odendaal 2012: pp466-473).

The ANC was formed in reaction to the exclusion of Africans from the political process at the formation of the Union of South Africa in 1910. The development of the ANC's political identity and its exclusive membership for Africans was rooted in the birth of the Union. The Union, an amalgamation of four provinces, was formed to represent the interests of English-speaking and Afrikaans-speaking whites in South Africa.

Dubow (2000: p1) writes the following: 'From its founding in 1912 and in the guise of its earlier incarnation, the South African Native National Congress, the ANC's political orientation pivoted on the need to defend and advance African civil and political rights against colonial discrimination and subjugation. Its founding leadership was constituted from the African elite. Educated and socialised in Western mores and customs, its members were driven to unite the range of scattered opposition movements to better contest colonial hegemony'.

It should be noted that the opposing principles and ideologies of the ANC were embedded in the long history of the movement. The ideological divide became prominent during the exile years of the ANC. Therefore, it became important to transform the image of the movement so as to be in line with the challenges experienced during the different time phases of its existence.

\section{Literature Review}

The researcher in this study departs from the premise that the ANC's history can be controversial. Many scholars of liberation movements have written about the ANC in and outside South Africa. Recently, a series of the South African Democracy Education Trust (SADET) books were published in attempts to write the history of the liberation struggle in South Africa. Other recent books published include (Rantete, 1998; Limb, 2010; Booysen, 2011; Southall, 2013; Ranchod, 2013; Mashele and Qobo, 2014). The above mentioned sources avoided the tendency of the construct which became known as 'patriotic history' in liberation movements' historiography. From the sources consulted, little is dedicated to the ideological shifts of the ANC since its formation in 1912. However, the lack of historiographical material setting out the ideological changes of the ANC provides historical legitimacy to this study. Therefore, this study may be seen as one of the academic contributions to the topic.

\section{Findings and Discussion}

For any movement, the question of having an ideological trademark(s) is important for its image, identification and survival. In most cases, political movements or organisations manage to stand the test of time by being identified with what they stand for ideologically. As indicated previously, some trademarks can change over time, depending on the political situation in which the movement finds itself.

\subsection{Forging the unity of Africans in South Africa}

The Constitution of the ANC, approved by the executive committee in 1918, stated that its aims included the achievement of universal adult franchise and the creation of a united democratic South Africa. The ANC promoted these ideals by sending petitions and delegations to the South African and British governments. Motshega (2010: p95) states that: 'One of the original purposes of the ANC was to bring together a wide variety of different ethnic groups and tribes, to bring about unity and cooperation between people of colour'. In the period from the ANC's establishment in 1912 through to the 1950s, ANC ideology was dominated by African nationalism. The ANC sought to further black interests, while white participation in the black African struggle was limited. ANC membership was exclusively black throughout this period. The formation of the Congress Alliance in the 1950s, which facilitated political cooperation amongst black, coloured and Indian activists saw a more integrated approach to the ANC's liberation efforts. 


\subsection{Promoting the nationalist agenda}

The fact that when the ANC was founded in 1912, the movement was known as the South African Native National Congress (SANNC), which changed to the ANC in 1923, thus indicating its commitment to the nationalist agenda of the African masses (Rantete 1998: p3). According to Southall (2013: p5) writers from different intellectual traditions stress the monopolistic tendencies within national liberation thought which challenge democratic ideals and the legitimacy of political difference. From the above perspective, it was clear that the liberation struggle was conceived by the liberation movements as revolving principally around 'self-determination' or in the South African case, the overthrow of apartheid, than it was about achieving democracy. The struggle was more about the equality of peoples as 'nations' than it was about equality for people as individuals (Southall 2003: pp255-272).

As early as 1911, Pixley ka Isaka Seme, one of the ANC's founding members, wrote that: 'The demons of racialism, the aberration of the Xhosa-Fingo feud, the animosity that exists between the Zulus and the Tsongas, between the Basothos and every other Native must be buried and forgotten; it has shed among us sufficient blood! We are one people. These divisions, these jealousies, are the cause of all our woes and of all our backwardness and ignorance today' (Meli 1988: p36).

\subsection{The question of non-racialism}

Although the ownership and meaning of the term 'non-racialism' remain highly contested, in the context of this study it is understood to imply the denial of race and its complete negation. In the 1920s the ANC adopted the question of nonracialism which opened it up to various influences. During this period, greater worker organisation, mixed with an ethos of non-racialism, prompted the ANC to establish closer relations with the Communist Party of South Africa (CPSA). The CPSA, formed in 1921, had embarked upon a contentious debate about the relationship between the national question and socialist revolution. (Ranchod 2013: pp2-3; Southall 2013: p31).

Close cooperation between the ANC and CPSA continued until 1927 when Seme expressed his opposition to the communist involvement in the black nationalist movement. In the 1930s the influence of the ANC declined, mainly due to the ineffectiveness of the movement; opposing factions within the groups; leadership disputes; and the failure of representations to the government to remove the grievances of blacks. Proponents of non-racialism believed that only through the denial of race could South African politics cease to be framed in racial terms, thus allowing for meaningful social change and greater equality.

In the 1950s, events such as the Defiance Campaign and the adoption of the Freedom Charter by the ANC further promoted the non-racialism agenda of the ANC. Without doubt, new levels of protest and dissent through civic mobilisation were achieved in the 1952 Defiance Campaign, and thereafter the decision to hold the Congress of the People (COP) in 1955. The Freedom Charter adopted there formed a pivotal moment in the narrative of the struggle for liberation. Ranchod (2013: p3) states that the Freedom Charter became the foundational text of an historical quest for freedom; a quest that would perform yeoman-like ideological service for the ANC. The Charter was the locus of disputation and a site of conflict for varying ideological factions in the ANC. The intensity of such conflict eventuated in the splintering of the ANC and the formation of the Africanist-oriented Pan Africanist Congress (PAC) which propagated the Africanist agenda. The statement 'the people shall govern' in the Freedom Charter is the origin of the notion of people's power in the context of non-racialism (Booysen 2011, p86). Ndebele (2001: p6) argues that the adoption of the Freedom Charter in 1955 was particularly important in highlighting cross-racial political cooperation.

In his article titled: The African National Congress and the policy of non-racialism: A study of the membership issued, Ndebele (2002: p133) grapples with the question of why non-racialism became central to the ANC. He argues that the adoption of the Freedom Charter as an official document came to play a significant role in the development of the ANC's non-racial politics. Significantly, the preamble to the Charter proclaimed that 'South Africa belongs to all who live in it, both black and white'. It should be noted that despite the above declaration by the ANC, it did not provide for automatic membership of supporters from others of apartheid's designated racial groups.

According to Everatt (2009: p3), in the late 1940s and early 1950s multiracial, non-racial, interracial and similar terms were used interchangeably. All these terms, at that time, referred to formal equality between the races. By the time the Second World War ended the ANC was campaigning unequivocally for full equality and increasingly used extraparliamentary methods, such as passive resistance campaigns in support of its struggle. 


\subsection{The struggle for multi-racialism}

There was a thin line between understanding the usage of the terms non-racialism and multi-racialism. In 1985 Oliver Tambo, President of the ANC stated the following on the difference between non-racialism and multi-racialism: 'There must be a difference. That is why we say non-racial. We could have said multi-racial if we had wanted to. There is a difference. We mean non-racial, rather than multi-racial. We mean non-racial, there is no racism. Multi-racial does not address the question of racism. Non-racial does. There will be no racism of any kind and therefore no discrimination that proceeds from the fact that people happen to be members of different races. That is what we understand by non-racial (Maré 2003: p3).

Multi-racialism was built on the belief that South Africa was not a unitary society, but rather constituted different and distinct races. These races were seen as all having different interests, based on their different cultures. This liberal multi-racialism sought to manage the relations among the different race groups in South Africa through what became known as constructive segregation. Multi-racialism of the early ANC was ultimately seen as an attempt to manage 'race relations' and accepted the racially separate political organs of the Congress Alliance. This approach was increasingly challenged from within the ANC, most notably by the African National Congress Youth League (ANCYL), where a more radical African nationalist position had begun to emerge in the 1940s. By the 1950s the multi-racial position of the ANC was the cause of major internal tensions, and ultimately led to a breakaway of the Africanists, who formed the PAC under the leadership of Robert Sobukwe (Petersen 2000: p7; Lodge 1994: pp104-122).

Sobukwe levelled the following criticism at the multi-racialism of the ANC: 'Against multi-racialism we have this objection, that the history of South Africa has fostered group prejudices and antagonisms, and if we have to maintain the same group exclusiveness, parading under the term multi-racialism, we shall be transporting to the new Africa these very antagonisms and conflicts ... It is a method of safeguarding white interests irrespective of population figures. In that sense it is a complete negation of democracy. It implies that there are such basic insuperable differences between the various national groups here that the best course is to keep them permanently distinctive in a kind of democratic apartheid. That to us is racialism multiplied, what is probably what the term truly connotes' (Petersen 2000: p7).

\subsection{The pro-business policies}

Limb (2010: pxii) argues that the pro-business policies of the ANC government in recent years seem to confirm a picture of the ANC's gradual alienation from workers, just as during the national liberation struggles across Africa, nationalist politicians invariably made good use of workers and then abandoned them.

According to Limb (2010: pxiii) it is certainly true that many politicians in many countries, including South Africa, tend to leave behind the policies, such as those enshrined in the Freedom Charter and the Reconstruction and Development Programme (RDP) that aimed to create jobs, safeguard health and the environment, and protect worker rights. However, in the post-apartheid era, Mashele and Qobo (2014: p9) criticised the ANC and claimed that it had difficulties in delivering on some of the RDP promises made during the electioneering periods. When it became the ruling party, it was revealed that the early enthusiasm of the transition period was not wholly realistic.

Southall (2013: p88) provides a view that the post-1994 ANC adapted global realities by implementing responsible pro-market strategies and returning the economy to levels of growth. The researcher argues in this study that despite the above, the ANC later abandoned the collectivist-oriented RDP in favour of the neo-liberal Growth, Employment and Redistribution (GEAR) strategy and to a certain extent, embraced free-market capitalism and was simply dubbed the '1996 class project'. This approach which was masterminded by Thabo Mbeki and Trevor Manuel seemed to have been an ambitious project for the slow growing economy of the ANC government. The project was mainly referred to as neoliberal by the South African Communist Party (SACP).

\subsection{Adopting the principles of democratic centralism}

Democratic centralism is the name given to the principles of internal organisation used by Leninist political parties; the term sometimes being used as a synonym for any Leninist policy inside a political party. The democratic aspect of this organisational method describes the freedom of members of the political party to discuss and debate matters of policy and direction, but once the decision of the party is made by majority vote, all members are expected to uphold that decision. Therefore, this latter aspect represents centralism. Although after the 1994 general elections in South Africa, through the new country's Constitution which provided for a distribution of power between the national state and the nine provinces, the ANC pursued a goal of greater centralisation. It is mainly argued that the issue of centralising power within 
the ANC came during the presidency of Mbeki. Mbeki's presidency was characterised by the consolidation of various government administrative departments into a few administrative committees. This move by Mbeki was viewed as an attempt to widen the gap between the ANC and his administration.

\subsection{Promotion of social democracy}

Contemporary South African political debate can oversimplify or even ignore the complicated and contested history of social and political thinking in the ANC. The 1943 African Claims document highlighted some socially important issues (Turok 2011: pp21-26). The then ANC President AB Xuma shifted the movement's focus from ethnic mobilisation to mass campaigning, and used the radical ideas which were prevalent during the anti-fascist struggle. These ideas involved equality of treatment for the whole population and included a bill of social rights; state medical services and compulsory education, as well as the extension of progressive labour legislation to all racial groups. This was the first clear formulation of social democratic ideas in the ANC.

The ANC first referred to the term 'social democracy' in its 2007 document known as the 'Strategy and Tactics' document. This document states that: 'The ANC therefore seeks to build democracy with social content. Informed by our own concrete conditions and experiences, this will, in some respects, reflect elements of the best traditions of social democracy, which include a system which places the needs of the poor and social issues such a health care, education and a social safety net at the top of the national agenda; intense role of the state in economic life; pursuit of full employment; quest for equality; strong partnership with the trade union movement; and promotion of international solidarity' (Potgieter-Gqubule 2010: p111).

\section{Conclusion}

It is clear from this study that the ANC has been through an ideological evolution in its history of existence. Contrary to the claims made by some ANC leaders, suggesting that the ANC has always been committed to certain ideologies such as non-racialism, the above analysis indicates that this ideal was not a consistent feature of ANC thinking. The ways in which the ideologies evolved within the ANC are clearly shown. In 1994, the ANC found itself on the unexpected terrain of reform, having come to power through a negotiated settlement that severely limited the possibility of bringing about radical social transformation.

\section{References}

Booysen S 2011. The African National Congress and the Regeneration of Political Power: 86. Johannesburg: Wits University Press. Dubow S 2000. The African National Congress: 1. Johannesburg: Jonathan Ball. Limb P 2010. The ANC's Early Years: Nation, Class and Place in South Africa before 1940: xii-xiii: Pretoria: UNISA Press.

Lodge T 1994. 'The Pan-Africanist Congress, 1959-1990', in Liebenberg I, Nel B, Lortan F and Van der Westhuizen G (eds.), The Long March: The story of the struggle for liberation in South Africa: 104-122. Pretoria: HAUM.

Maré G 2003. 'Non-racialism in the struggle against apartheid'. In Society in Transition 34(1): 3.

Mashele P and Qobo M 2014. The Fall of the ANC: What Next?: 9: Johannesburg: Picador Africa.

Meli F 1988. A History of the African National Congress: South Africa belongs to us: 36. London: James Curry.

Motshega M 2010. 'Pan-Africanism', in Turok B (ed.), The historical roots of the ANC: 95. Sunnyside: Jacana.

Ndebele N 2001. 'The ANC's commitment to non-racialism: 'The question of open membership, 1960-1990', MA Thesis: 6. Johannesburg: University of the Witwatersrand.

Ndebele N 2002. 'The African National Congress and the policy of non-racialism: A study of the membership issue'. In Politikon 29(2): 133.

Odendaal A 2012. The founders: The origins of the ANC and the struggle for democracy in South Africa: 466-473. Sunnyside: Jacana.

Petersen RM 2000. 'Discourses of difference and sameness', in Cochrane JR and Klein B (eds.), Sameness and Difference: Problems and Potentials in South African Civil Society: South African Philosophical Studies I.

Potgieter-Gqubule F 2010. 'Social Democracy', in Turok B (ed.), The historical roots of the ANC: 95. Sunnyside: Jacana.

Ranchod R 2013. A Kind of Magic: The Political Marketing of the ANC: 2-3. Sunnyside: Jacana.

Rantete J 1998. The African National Congress and the Negotiated Settlement in South Africa. 3: Pretoria: Van Schaik Publishers.

Southall R 2003. 'Democracy in Southern Africa: Moving beyond a difficult legacy'. In Review of African Political Economy 30: $255-272$.

Southall R 2013. Liberation Movements in Power: Party and State in Southern Africa: 5, 31, 88: Pietermaritzburg: University of KwaZuluNatal Press.

Turok B 2011. Readings in the ANC Tradition: Policy and Praxis, Vol 1: 21-26. Sunnyside: Jacana. 